\title{
Correction to: Suicidal ideation, psychopathology and associated factors among HIV-infected adults in Indonesia
}

Youdiil Ophinni ${ }^{1}$, Adrian ${ }^{2}$, Kristiana Siste ${ }^{2 *}$, Martina Wiwie ${ }^{2}$, Gina Anindyajati ${ }^{2}$, Enjeline Hanafi ${ }^{2}$, Reza Damayanti ${ }^{2}$ and Yoshitake Hayashi ${ }^{1}$

\section{Correction to: BMC Psychiatry 20, 255 (2020) https://doi.org/10.1186/s12888-020-02666-1}

Following publication of the original article [1], an error was identified in the Results section of the Abstract.

The updated result is given below and the changes have been highlighted in bold typeface.

Results:

Multivariate analysis identified that a single-point increase in SCL-90 depression symptoms score (AOR 1.26, 95\% CI 1.08-1.48, $p=0.004$ and efavirenz use (AOR 5.00, 95\% CI 1.02-24.6, $p=0.048$ ) were significant independent factors related to suicidal ideation.

\section{Author details}

'Department of Pathology, Graduate School of Medicine, Kobe University,

Kobe, Japan. ${ }^{2}$ Department of Psychiatry, Faculty of Medicine, Universitas

Indonesia, 71 Diponegoro, Central Jakarta, DKI, Jakarta, Indonesia.

Published online: 20 October 2020

\section{Reference}

1. Ophinni, et al. Suicidal ideation, psychopathology and associated factors

among HIV-infected adults in Indonesia. BMC Psychiatry. 2020;20:255.

https://doi.org/10.1186/s12888-020-02666-1.

The original article can be found online at https://doi.org/10.1186/s12888020-02666-1.

* Correspondence: ksiste@yahoo.com

${ }^{2}$ Department of Psychiatry, Faculty of Medicine, Universitas Indonesia, 71

Diponegoro, Central Jakarta, DKI, Jakarta, Indonesia

Full list of author information is available at the end of the article

(c) The Author(s). 2020 Open Access This article is licensed under a Creative Commons Attribution 4.0 International License, which permits use, sharing, adaptation, distribution and reproduction in any medium or format, as long as you give appropriate credit to the original author(s) and the source, provide a link to the Creative Commons licence, and indicate if changes were made. The images or other third party material in this article are included in the article's Creative Commons. licence, unless indicated otherwise in a credit line to the material. If material is not included in the article's Creative Commons licence and your intended use is not permitted by statutory regulation or exceeds the permitted use, you will need to obtain permission directly from the copyright holder. To view a copy of this licence, visit http://creativecommons.org/licenses/by/4.0/ The Creative Commons Public Domain Dedication waiver (http://creativecommons.org/publicdomain/zero/1.0/) applies to the data made available in this article, unless otherwise stated in a credit line to the data. 